\title{
Bir Çeviri Etiği Dersine Doğru
}

\section{Banu TELLIOĞLUU1}

\author{
$\ddot{O} z$
}

Çeviri etiğine duyulan ilginin özellikle son 20 yıldır artmakta olduğunu söyleyebiliriz. Bu ilginin en temel göstergeleri, çeviri etiğinin bir meslek etiği gibi algılanması gerektiği yolundaki düşüncelerin hem çeviribilimciler hem de sektör temsilcileri tarafindan giderek daha sıklıkla dile getirilmesi ve farklı meslek örgütleri tarafından yazılan meslek ilkelerinin sayısındaki ciddi artıştır. Çeviri etiğine duyulan ilginin yansımalarını çeviri eğitimi alanında da görmek mümkündür. Dünyada ve Türkiye'de çeviri etiği dersi yavaş yavaş çeviribilim bölümlerinin lisans müfredatlarında yerini almaktadır. Bunlar olumlu gelişmeler olmakla beraber, daha yeni yeni yaygınlaşmaya başlayan bu derslerin amaç, kapsam ve yöntemleri üzerine çok kapsamlı tartışmaların bulunmaması ve özellikle de farklı alanlarda çalışan çevirmenler için o alanlara özgü ve giderek daha kapsayıcı meslek ilkeleri yazma eğilimi dikkate alındığında, çeviri etiği eğitimi bağlamında olası bir tehlikeden söz etmek mümkündür: Çeviri eğitimcilerinin, meslek ilkelerini öğrencilere belleterek daha ahlaklı çevirmenler yetiştirebilecekleri inancıyla çeviri etiği derslerini meslek ilkeleri odağında yürütmeleri. Bu bildirinin amacı çeviribilim bölümlerinde lisans müfredatına yerleştirilecek bir çeviri etiği dersinde sözü edilen tehlikeden nasıl kaçınabileceğimizi araştırmaktır. Bu doğrultuda öncelikle çeviri etiği alt alanının kapsamına değinilecek ve meslek ilkeleri doğrultusunda hareket etmenin çevirmeni niçin ahlaklı bir birey yapmaya yetmeyeceği üzerinde durulacaktır. Daha sonra, lisans müfredatlarına yerleştirilecek bir çeviri etiği dersinin amaç ve kapsamı ve bu derste kullanılabilecek yöntemler tartışlacak, böylelikle özgürleştirici, çevirmenin bireysel sorumluluklarının altını çizen bir çeviri etiği dersinin genel çerçevesi belirlenmeye çalışılacaktır.

Anahtar kelimeler: Çeviri eğitimi, çeviri etiği, meslek ilkeleri, çevirmenin sorumluluğu.

\section{Towards a Course on Translation Ethics}

\begin{abstract}
The growing interest in translation ethics for the last 20 years has been well manifested in the often stated need to regard translation ethics as professional ethics and in the increasing number of professional codes and standards written by various professional organizations and chambers. The repercussions of this interest in translation ethics can also be felt in translation training. Translation ethics is now integrated in the curricula of many translation studies undergraduate programs both in the world and in Turkey. These are all positive developments; however, when we consider the insufficient number of academic discussions concerning the aims, the content and the methodology of such courses and the clear tendency among professional organizations to create more comprehensive and field specific professional codes and standards for translators working in different sectors, we cannot but foresee a danger: that trainers might believe professional codes guarantee ethical behavior and instruct their students to follow professional codes unquestioningly. The paper seeks to investigate how this danger could be avoided in an undergraduate course on translation ethics. The first part of the paper presents the scope of translation ethics and discusses
\end{abstract}

Dr. Öğr. Üye. Kırklareli Üniversitesi, Fen Edebiyat Fakültesi, Mütercim-Tercümanlık Bölümü, banutelli@gmail.com [Makale kayıt tarihi: 28.6.2018-kabul tarihi: 15.8.2018] 


\begin{abstract}
whether following professional codes and standards might suffice to make translators moral individuals. Discussing the possible aims, content and methodology of a course on translation ethics, the second part attempts to propose a general framework for a more liberating undergraduate course which underlines translators' individual moral decisions and responsibilities.
\end{abstract}

Key words: Translation training, translation ethics, professional codes, translator's accountability.

\title{
Bir Çeviri Etiği Dersine Doğru
}

Çeviri etiği son 20 yıldır çeviribilimde ve genel olarak çeviri dünyasında en çok tartışılan konulardan biri oldu. Bunun en önemli nedenlerinden biri dünyada etiğe, özellikle de meslek etiğine duyulan ilginin artmasıdır. Bilimsel ve teknolojik gelişmelerin büyük bir hızla yaşamımızı değiştirdiği günümüz dünyasında, bu gelişmelere bağlı olarak ortaya çıkan yeni uygulamaların ahlaki sonuçlarıyla ilgili kaygı duymamamı neredeyse olanaksız. Öte yandan, bilim ve teknolojideki ilerlemeler sayesinde hemen hemen her meslekte yeni uzmanlık alanları ortaya çıkıor; buna bağlı olarak da meslekte uzmanlaşmanın önemi giderek artıyor. Bütün bu gelişmeler dünyada meslek etiğine duyulan gereksinimin daha fazla dile getirilmesine neden oluyor. Kuşkusuz çeviribilim alanı da bu gelişmelerden fazlasıyla etkileniyor. Bir yandan, bilgisayar destekli çeviri araçları ve makine çevirisi çevirinin ve çevirmenin klasik tanımını sürekli değiştirir, çevirinin ve çevirmenliğin geleceğini sorgulamamıza yol açarken, öte yandan toplumsal ve siyasi gelişmeler, savaşlar ve göç olayları nedeniyle mahkeme ve toplum çevirmenliği, afette çevirmenlik gibi alt alanların ağırlık kazanması birey olarak çevirmenin karşılaşacağı ahlaki açmazların kolayca üstesinden gelmesine yarayacak meslek ilkelerinin oluşturulması gerektiği düşüncesini pekiştiriyor. Akademisyenler, sektör temsilcileri ve hatta çevirmenlerin kendileri artık çevirinin de bir meslek olarak algılanması gerektiği, çevirinin doğası gereği ahlaki çatışmaları içinde barındıran bir etkinlik olduğu ve bu çatışmaların çözümlenmesine yarayacak, çevirmenlik mesleğine özgü meslek ilkeleri oluşturulması gerektiği yönünde görüş bildiriyorlar. Bunun doğal bir sonucu olarak, her gün yeni meslek ilkeleri, meslek standartları yazılıyor, yemin önerileri sunuluyor. Çeviri eğitimi alanında da çeviri etiğine duyulan ilginin arttığına tanık oluyoruz. Çeviri etiği dersleri Türkiye'de ve dünyada yavaş yavaş çeviribilim bölümlerinin lisans müfredatlarına alınmaya başlıyor yahut en azından farklı alan derslerinin içine entegre ediliyor. Bunlar olumlu gelişmeler olmakla beraber, daha yeni yeni yaygınlaşmaya başlayan bu derslerin amaç, kapsam ve yöntemleri üzerine çok kapsamlı tartışmaların bulunmaması ve özellikle de farklı alanlarda çalışan çevirmenler için o alanlara özgü ve giderek daha kapsayıcı meslek ilkeleri yazma eğilimi dikkate alındığında, çeviri etiği eğitimi bağlamında olası bir tehlikeden söz etmek mümkün: Çeviri eğitimcilerinin, meslek ilkelerini öğrencilere belleterek daha ahlaklı çevirmenler yetiştirebilecekleri inancıyla çeviri etiği derslerini meslek ilkeleri odağında yürütmeleri. Mona Baker ve Carol Maier (2011) bu tehlikenin işaretlerini şu sözlerle özetliyorlar:

Üniversitelerdeki yazılı ve sözlü çeviri eğitimcileri bu güne kadar öğrencilerine meslek ilkelerini hiç sorgulamadan uygulamaları gerektiğini öğrettiler; öğrencilerin bu yazıda ele aldığımız ahlaki meselelere ilişkin derin bir kavrayış geliştirmelerine yardımcı olmak konusunda da yetersiz kaldılar. $\left(\right.$ s. 2) ${ }^{2}$

Bu bildiri, çeviribilim bölümlerinde lisans müfredatına yerleştirilecek bir çeviri etiği dersinde sözü edilen tehlikeden nasıl kaçınabileceğimizi araştırmayı amaçlıyor. Bu doğrultuda öncelikle çeviri etiği alt alanının kapsamına değinilecek ve meslek ilkeleri doğrultusunda hareket etmenin çevirmeni ahlaklı bir birey yapmaya yetip yetmeyeceği sorusuna yanıt aranacak. Daha sonra lisans müfredatlarına

2 Aksi belirtilmedikçe tüm çeviriler bana aittir. 
yerleştirilecek bir çeviri etiği dersinin amaç ve kapsamı ve bu derste kullanılabilecek yöntemler tartışlacak, böylelikle özgürleştirici, çevirmenin bireysel sorumluluklarının altını çizen bir çeviri etiği dersinin genel çerçevesi belirlenmeye çalışılacak.

\section{Çeviri etiği neleri kapsar?}

Çeviri etiği temelde çevirmen hakları ile çevirmenin sorumlulukları ve özgürlükleri üzerinde durur. Çevirmen hakları bağlamındaki tartışmalarda genellikle telif hakları, çevirmenin yaptığı iş karşılığında alacağı ücret, çalışma koşulları ve işi bırakma ya da reddetme hakkı olup olmadığı gibi sorular üzerine odaklanıldığına tanık oluruz. Çevirmenin sorumlulukları (ve bununla doğrudan ilintili olarak çevirmenin özgürlükleri) başlı̆̆ altında ise çevirmenin öncelikli olarak kime/neye karşı sorumlu olduğu ve çevirmenin karar alırken ne ölçüde özgür olduğu yolundaki sorulara yanıt aranır. Çevirmen öncelikle kime/neye karşı sorumludur? İşverenine mi? Erek ya da kaynak kültürün okuruna mı? Yoksa kaynak metnin yazarına mı? Çevirmen kaynak metnin işlevini korumakla mı yükümlüdür, yoksa çeviri metnin erek kültürde göreceği işlevi göz önünde bulundurmakla mı? Çevirmen ne ölçüde görünür olmalıdır? Çeviri denklemi içinde çevirmenin kendi dünya görüşü, bakış açısı, ideolojisi nasıl ve ne ölçüde rol oynamalıdır? Yoksa çevirmenlik bireysellikten tümüyle arınmayı, her koşulda nesnelliği korumayı mı gerektirir? Eğer öyleyse çevirmen taraflar arasında güç eşitsizliğinin aşikâr olduğu durumlarda -ki bu tür durumlar çevirmenlerin çok sık karşılaştı̆̆ durumlardır- tam bir nesnelliği hedefleyerek her iki tarafa da eşit mesafede mi durmalıdır? Yoksa bireysel ahlaki itkileri uyarınca güçsüzden yana mı tavır almalıdır? Çevirmen çeviriyi kendi aktivist yaklaşımının bir aracı olarak kullanabilir mi?

Aslında tarih boyunca çeviri üzerine yürütülen tartışmaların çoğunun bu soru ve sorunlar çevresinde şekillendiğini söylemek yanlış olmayacaktır. Her çeviri tanımı, bir bakıma, çevirinin nasıl yapılması gerektiği, çevirmenin nasıl davranması gerektiği yolunda bir görüşü de içinde barındırır. Çevirmenler, düşünürler, edebiyatçılar, dilbilimciler, akademisyenler ve çeviri kuramcıları çeviriyi nasıl değerlendirdiklerine ya da ne açıdan ele aldıklarına bağlı olarak yukarıda sıraladığımız soru ve sorunlara yanıt aradılar, çözüm getirmeye çalıştılar. Yani çeviri etiği, üzerine yeni düşünmeye başladığımız bir konu değil. Yukarıda değindiğimiz meseleler üzerine yüzyıllar boyu yapılagelen tartışmalar özellikle 9o'lı yıllardan sonra çeviribilim kuramında yepyeni bir anlayışla devam etti. Çeviribilim kuramcıları yapısalcılık ve sömürgecilik sonrası düşüncenin de etkisiyle çevirmenin kendi kültürü ve ideolojisi doğrultusunda hareket edebilecek, çeviriye ilişkin kararları bu doğrultuda alarak bireysel ahlaki seçimlerini görünür kılabilecek, hatta çeviriyi dünya görüşünü ortaya koymak, aktivist eğilimlerini gerçekleştirmek için bir araç olarak kullanabilecek ve çevirinin bütün sorumluluğunu üstlenecek bir birey olarak algılanması gerektiğinden söz etmeye başladılar. Ancak biraz önce değindiğimiz gibi, genel olarak dünyadaki, özel olarak da çeviri alanındaki gelişmeler çeviri etiğinin kuramsal alanda ifade edilen özgürleştirici düşüncelerden uzaklaşmasına, etik bağlamında aynı soru ve sorunların tekrar tekrar ama kuramsal alandakinden çok farklı bir anlayışla ele alınmasına yol açıyor. Bireyin seçimlerine bağlı ve belirsizlikleri içinde barındıran bir etkinlik olarak çevirinin denetim altında tutulması gereken bir etkinlik olduğu görüşü ağırlık kazanmaya başlıyor. Sakine Eruz’un "Çeviri Derneği ve Türkiye'de Çevirmenlik Mesleğinin Statüye Kavuş(a)ma(ma)sı Üzerine On Üç Yıllık Gel Gitli Bir Öykü” (2012) başlıklı yazısında ifade ettiği gibi "sınırları muğlak etik konusu Demokles'in kılıcı gibi üzerimizdeki boşlukta bizi tehdit edercesine sallanıyor” (s. 19). Bu belirsizlikten kurtulmanın yolu ise pek çokları için çeviri etkinliklerini meslek ilkeleri aracıllğıyla denetlemekten geçiyor. Bugün çeviri etiğinin deontolojik kodlarla şekillenen bir meslek etiği olarak değerlendirilmesi, her alt alan için ayrıntılı meslek ilkelerinin oluşturulması ve çeviriye ilişkin kararların bu yolla denetlenmesi gerektiği yolundaki inancın giderek güçlendiğine tanık oluyoruz. Bu noktada şunu söylemek yanlış olmayacaktır: Günümüzde meslek 
ilkeleri sözü edilen çetrefilli soru ve sorunlarla başa çıkmamıza yarayacak birer çare gibi algılanmakta, bunların çevirmenin karşılaşacağı ahlaki açmazlardan kolayca kurtulmasını sağlayacağı varsayılmaktadır. Bu varsayımın en belirgin yansıması dünyadaki ve Türkiye'deki çeviri meslek örgütlerinin kendi meslek ilkelerini ortaya koymak ve bu ilkelere ilişkin eğitim programları sunmak için adeta birbirleriyle yarışmasıdır.

\section{Meslek ilkelerinin sınırları}

Kısaca ifade etmek gerekirse, meslek ilkeleri belli bir meslek mensubunun mesleğini icra ederken nasıl davranması gerektiğini ifade eden kurallar bütünüdür. Bunlar, temelde, bir meslekte kabul görebilecek ya da görmeyecek davranışlar ya da uygulamalar konusunda bilgi vermek, böylece meslek mensubunun bazı insani ya da mesleki değerlere aykırı davranmasını önlemek amacıyla meslek odaları, meslek birlikleri ve federasyonlar yahut başka kurum ve kuruluşlar tarafindan oluşturulan ilkelerdir3. Bu türden meslek örgütleri tarafından oluşturulan ilkelere şöyle bir göz atıldığında "tarafsızlık", "nesnellik", "gizlilik", "doğruluk", "sadakat" ve "çevirinin eksiksizliği" ilkelerinin öne çıktığı görülür. Peki, belli durumlarda nasıl davranılması gerektiğini ortaya koymayı amaçlayan bu meslek ilkeleri, çevirmenlerin her durumda ahlaka uygun seçimler yapmalarını sağlayabilir mi? Çeviri mesleğine özgü ilkelerin varlığı, her tek çevirinin ahlaka uygun yapılmasını garantileyebilir mi? Meslek ilkeleri doğrultusunda hareket etmek çevirmenleri ahlaklı bireyler yapmaya yeter mi? Bu sorulara "hayır" yanıtını vereceğim.

Öncelikle, meslek ilkeleri her tek durumu kapsayacak biçimde ayrıntılandırılamayacak, karşlaşllabilecek her türlü ahlaki çelişkiyi çözmeye yetmeyecektir. Basın meslek ilkelerinden söz ettiği “'Basın Etiği’ ya da Basının Etik Sorunları” (2009) başlıklı yazısında Harun Tepe şöyle diyor:

[...] kişinin -gazetecinin- yaşadığı̆ her durum, -durumlar, olaylar arasında kimi ortak yanlar olsa datektir, bir kereliktir. Belirli zamanda ve yerde yaşanır, sona erer. Bu nedenle, belirli durumlarda nelerin yapılıp nelerin yapılmayacağını dile getiren basın meslek ilkeleri, tüm diğer meslek ilkeleri gibi tek başına doğru değerlendirmeyi sağlayamazlar. (s. 150)

Ahlaki çatışma içeren her durumun tekil olduğunu ortaya koyan bu alıntıdan da anlaşlacağı üzere, meslek ilkelerinin, yani kısa ve özlü biçimde ifade edilen, bu nedenle de çokça genelleme barındıran deontolojik kodların her tek durumda çevirmene yol gösteremeyeceği açıktır.

Öte yandan, meslek ilkelerinin daha kapsayıcı ve ayrıntılı hale getirilmesi birbiriyle çelişen ilkeler yazılması olasılığını artırır ya da en azından çevirmenin belli bir ilkeden çelişkili sonuçlar çıkarmasına yol açabilir. Bu da onun karar alma sürecini kolaylaştırmak yerine zorlaştırabilir. Julie McDonough Dolmaya farklı meslek örgütleri tarafından ortaya koyulan meslek ilkelerini incelediği "Moral Ambiguity: Some Shortcomings of Professional Codes of Ethics for Translators" [“Ahlaki Müphemlik: Çevirmenlere Yönelik Meslek İlkelerinin Bazı Yetersizlikleri”] (2011) başlıklı makalesinde meseleyi şöyle ele alıyor:

[Ç]eviri kuruluşlarının gözünde, meslek etiğine uygun davranan çevirmen o kuruluşların meslek ilkelerine uygun davranan çevirmendir. Bu da şu demek oluyor: Bir çevirmenin ahlaklı davranıp davranmadığı hangi kuruluş için çalıştı̆̆ına bağlıdır çünkü çeviriye ilişkin ahlaklı davranışın ne olması gerektiği konusunda [farklı kuruluşlar tarafindan üretilen farklı meslek ilkeleri] arasında bir tutarlılk yoktur. Dahası, bu ilkelerde mesleğin belli unsurları ele alınmıyorsa [...], çevirmenler [o belli unsurlarla ilgili olarak] nasil davranabileceklerini gösteren bir kllavuzdan yoksun kalıyorlar demektir. (s.45; vurgular bana ait)

3 Meslek örgütlerinin yayınladığı meslek ilkelerine ilişkin ayrıntılı bir inceleme için bkz. Tellioğlu, 2015. 
Bu görüşler doğrultusunda, örneğin, "gizlilik ilkesi uyarınca hareket etmek başkalarının yararına ya da kamu yararına sonuçlar doğurmayabilir" (Drugon ve Megone, 2011, s. 202). Öyleyse "gizlilik" ilkesi doğrultusunda hareket etmeye koşullanmış bir çevirmenden ülke güvenliğini ilgilendiren ya da halk sağlığını açıkça tehdit eden bir ürüne ilişkin bir metin çevirmesi istendiğinde çevirmen ne yapacak? "Gizlilik” ilkesi uyarınca öncelikle işverenine sadakat gösterip elindeki önemli bilgileri ifşa etmeyecek mi? Yahut bu bilgileri ifşa ederse ne tür sonuçlarla karşlaşacak? Bir başka örnek üzerinden düşünelim: Pek çok meslek örgütünün bildirgesi içinde yer alan "sadakat" ilkesi uyarınca sözcüğü sözcüğüne çeviri yapan bir çevirmen ortaya çıkardığı metnin erek kültürde anlamlı bir işlev üstlenmediğini gördüğünde kuşkusuz bocalayacaktır. "Sadakat" özellikle de güç eşitsizliğinin söz konusu olduğu durumlarda, çevirmenin bu eşitsizliğin hangi yakasında yer aldığına bağlı olarak, bazen kaynak metindeki yabancılığın korunması suretiyle erek kültürün zenginleşmesi, bazen de kaynak metne ya da kültüre ait öğelerin gereksiz biçimde erek kültüre aktarılması, bir bakıma empoze edilmesi biçiminde değerlendirilebilir.

Meslek ilkelerine ilişkin bir başka sorun da bu ilkelerin birer norm olmasından, normların ise zamana, mekâna ve toplumsal eğilimlere göre değişebilir olmasından kaynaklanır. Her norm uygun biçimde temellendirildiğinde evrensel olarak geçerli kılınabilir. Bu da esasen her biri birer norm olan meslek ilkelerinin pekâlâ "iktidar sahiplerinin çıkarları" doğrultusunda temellendirilebileceğine işarettir (Kuçuradi, 2009, 33). Öyleyse, meslek ilkelerinin zaman zaman güçlü olana ve yaygın ideolojiye hizmet ediyor olması bizi şaşırtmamalı. Örneğin, bildirinin ilerleyen bölümlerinde daha ayrıntılı biçimde ele alacağım ve taraflar arası güç eşitsizliğinin en belirgin biçimde ortaya çıktığı sığınma başvurusu duruşmalarında "tarafsızlık" ilkesi mahkeme çevirmenini tarafsız olmaya çalışırken kaçınılmaz olarak güçlüden yana bir tavır almaya yönlendirebilir.

Meslek ilkeleriyle ilgili belki de en önemli sorun da şudur: Belli meslek ilkeleri çerçevesinde hareket etmeye koşullanan ve böylece "hata" yapması engellenen çevirmen yaptığı işin nihai sonuçları üzerine kafa yormayı bırakabilir; yani bireysel ahlaki sorumluluklarını unutabilir. Jacques Derrida'ya (1991/1992) göre kural ya da ilkeler doğrultusunda yapılan seçimleri bireyin kendi seçimleri olarak değerlendirmek mümkün değildir. Bu tür seçimlerde kararı veren aslında kişinin kendisi değil, kural ya da ilkeyi koyandır. Dolayısıyla, hiç sorgulamadan kendisi için çizilen yolda ilerleyen birey, kendi bireysel ahlaki sorumluluklarından kurtulacak ve verdiği kararın vicdani yükünü hissetmeden yaşayıp gidecektir (s. 41).

Bütün bu sıraladığımız nedenlerden ötürü meslek ilkelerinin hiç sorgulanmadan benimsenmesi, çeviri etiği eğitiminin temeline yalnızca bu ilkelerin oturtulması ve öğrencilere bu ilkelerin körü körüne belletilmesi çeviri uygulamalarının her birinde çevirmenlerin ahlaki seçimler yapmalarını garantilemeyecek, bu ilkelerin varlığına rağmen karar alma sürecinde bocalamalarına engel olamayacak, üstelik onları ahlaki seçimler yapan ve işin nihai sorumluluğunu üstlenmesi gereken birer birey gibi davranmaktan alıkoyacaktır. Gene Harun Tepe'nin (2009) sözleriyle ifade etmek gerekirse, "[b]elki birçok meslek etiğinin yaptığı gibi, o meslek mensuplarının belirli durumlarda nasıl davranmaları gerektiğini dile getiren ilkeler, değerlendirme ve eylem normları ortaya konulabilir. Kişiler bu normlara göre davranmaya da zorlanabilir. Ama bu tek başına ne doğru değerlendirmeyi sağlar, ne de etik eylemeyi” (s. 149). Doğru değerlendirme ve ahlaklı davranış, Zygmunt Bauman'ın (1998) da belirttiği gibi kişilerin bireysel olarak öğrenmeleri gereken şeylerdir. Ahlaki seçimlerin bireysel olduğunu, ahlakın ancak bireysel seçimlerin varlığında söz konusu olabileceğini iddia ettiği Postmodern Etik adlı yapıtında şöyle diyor Bauman: 


\begin{abstract}
Meselelerin önceden belirlenmiş çözümleri yoktur; içkin bir şekilde tercih edilebilir yönlerin bulunduğu yol ayrımları da yoktur. Sonucu iyi olmayacak durumlardan kaçınmak, alınan ve gerçekleştirilen kararların ardından istenmeden gelen acı bir ağız tadından [...] uzak durmak için öğrenebileceğimiz, ezberleyebileceğimiz ve kullanabileceğimiz kesin ilkeler yoktur. İnsan gerçekliği karışık ve müphemdir; dolayısıyla soyut etik ilkelerin tersine ahlaki kararlar da müphemdir. Biz böyle bir dünyada yaşamak zorundayız. [...] İlkesiz bir ahlak, temelleri olmayan bir ahlak düşünemeyen endişeli felsefecilere meydan okurcasına, her gün böyle bir dünyada yaşayabileceğimizi veya yaşamayı başardığımızı gösteriyoruz. (çev. Alev Türker, s. 46)
\end{abstract}

Peki, eğer ahlaklı birey olmanın garantisi biçiminde yorumlayamayacağımız ahlak kodları ve meslek ilkeleri çeviri etiği eğitiminin en vazgeçilmez öğesi olmayacaksa, lisans düzeyinde verilecek bir çeviri etiği dersi nasıl bir anlayış üzerine temellenmelidir?

\title{
Nasıl bir çeviri etiği dersi?
}

Harun Tepe'ye göre (2009) "[m]eslek etiklerinden genellikle beklenildiği gibi, her tek durumda, ya da belirli tipten durumlarda neyin yapılıp neyin yapılamayacağının reçetesini [...] sunamaz etik eğitimi” (s. 159). Etik eğitiminde esas, bireye ahlaki sorunları tespit edebilme ve bu sorunlar bağlamında doğru değerlendirme yapabilme olanaklarının sunulmasıdır. Bu da "etik ilişki, eylem, değerlendirme ve değer/değerler konularında bilgi vermekle", yani, etik bağlamında bir bilinç uyandırılması yoluyla yapılabilir (s. 157). Doğrudan çeviri etiği eğitimiyle ilgili olarak kaleme alınan sınırlı sayıda çalışmada da aslında bu türden bir yaklaşımın izlerini görmek mümkün. "The Ethics of Translation in Contemporary Approaches to Translator Training" [“Çeviri Eğitimine Çağdaş Yaklaşımlarda Çeviri Etiği”] (2005) başlıklı yazısında Rosemary Arrojo, eğer çevirinin çevirmenin inanç ve değer sistemiyle şekillenen, onun kültür ve ideolojisinden doğrudan etkilenen bir etkinlik olduğunu kabul ediyorsak bu anlayışımızın "pedagojik yaklaşımımıza da açıkça yansıma[sı gerektiğini]” iddia eder (s. 231). Çalışmasında net bir yöntem sunmaktansa genel bir çerçeve çizmeyi seçen kuramcıya göre, eğitmenin en önemli görevlerinden biri “öğrencilerin çeviri metnin üretilmesinde çevirmenin kaçınılmaz olarak belirleyici bir rol üstlendiğini anlamalarına yardımcı olmak[tır]” çünkü öğrenciler ancak bu şekilde çevirinin ne denli karmaşık bir iş olduğunu ve "en önemlisi, bu işi yapmayı kabul ederek ne kadar büyük bir sorumluluk üstlendiklerini” idrak edebilirler (s. 239). "Bringing Ethics into Translator Training" ["Çeviri Eğitimine Etiği Katmak"] (2011) başlıklı makalelerinde gene çeviri etiği eğitimini konu edinen ve bu eğitimin dikkatle tasarlanmış senaryolar üzerinden verilmesi gerektiğini iddia eden Joanna Drugon ve Chris Megone’a göre ise çeviri etiği eğitiminin temel amacı "öğrencilerin belli durumlarda ortaya çıkan ahlaki meseleleri tespit edebilmelerini, bunların kendi ahlaki seçimlerini nasıl etkileyeceğini analiz edebilmelerini ve dolayısıyla da, karşı karşıya kalınan durumda en etkili biçimde davranmak için nasıl eyleme geçeceklerine ilişkin bir karar alabilmelerini sağlamaktır” (s. 188). Çalışmasında radikal eğitim kavramına değinen ve tasarladığg çeviri etiği dersinin işleyişini öğrenci günlükleri üzerine kuran Kristiina Abdallah (2011) da meslek ilkelerinin yetersizliğine değinerek çeviri etiği dersinin yalnızca deontolojik meseleler üzerinde duramayacağını ve bu ders bağlamında ahlaki açmazların kendi bağlamlarından kopuk biçimde ele alınmaması gerektiğini dile getirir (s. 132). Ona göre de çeviri etiği dersinin amacı "ahlaki kararlar alma konusunda [öğrencilere] yol göstermek[tir]" (s. 129). Çeviri etiği dersinin nasıl yapılması gerektiğgini en ayrıntılı biçimde ele alan çalışma ise Mona Baker ve Carol Maier’e aittir. Araştırmacılar "Ethics in Interpreter and Translator Training" ["Yazılı ve Sözlü Çeviri Eğitiminde Etik”] (2011) başlıklı çalışmalarında çevirmenin sorumluluğu kavramı üzerinde durarak çevirmenlerin bireysel ahlaki seçimler yapmak konusunda dikkatli ve bilinçli davranmaları gerektiğini çünkü bu seçimlerin başkalarının hayatını doğrudan etkileyebileceğini, dolayısıyla da çevirmenlerin yaptıkları seçimleri açıklayabilecek, destekleyebilecek yeterlilikte olmaları gerektiğini belirtirler. Mona Baker ve Carol Maier'e göre lisans müfredatına yerleştirilmesi gereken çeviri etiği dersi "katı, soyut meslek 
ilkeleri” odağında değil, çevirmen adaylarının mesleki hayatlarında almak zorunda kalacakları ahlaki kararların vurgulanacağı gerçek durumlar odağında, eğitmenin sunacağı senaryolar üzerinden yapılacak sınıf içi tartışmalarla yürütülmelidir (s. 3).

\section{Öğrenci profili ve derste karşılaşılabilecek zorluklar}

Bütün bu görüşlerden yola çıkarak oluşturmaya çalıştı̆̆ım lisans düzeyindeki bu çeviri etiği dersi nasıl bir öğrenci profili hedefler? Dersin hedeflediği kitle çeviri kuramlarına, özellikle de yapısalcılık sonrası ve sömürgecilik sonrası yaklaşımlara aşina, toplumsal cinsiyet, uygarlık tarihi ve metin inceleme gibi dersler almış, çeviri becerilerini farklı çeviri derslerinde belli ölçüde geliştirmiş lisans 3. ya da 4. sınıfta öğrenim görmekte olan çeviribilim öğrencileridir. Ancak öğrencilerin sözü edilen konularda kendilerini bir ölçüde geliştirmiş olmaları bu derste bir takım zorluklarla karşılaşılmayacağı anlamına gelmiyor. Dolayısıyla, derste karşılaşılabilecek zorlukları önceden kestirmeye ve bunlara karşı önlem almaya çalışmanın da faydalı olacağı kanısındayım. Ders ile ilgili olarak yaşanabilecek en temel sorun derste benimsenen yaklaşımın öğrencilerin başka derslerde öğrendikleri bilgilerle ya da edindikleri yaklaşımlarla çelişmesidir. Bu durum, kuşkusuz, onların çeviri etiğine ilişkin tutarlı ve bütünleşik bir yaklaşım geliştirmesini engelleyecektir. Sorunun üstesinden gelmek ise ancak bölüm öğretim elemanlarının aynı temel anlayışı paylaşmasıyla ve uygulama derslerinin içine etik sorunlara ilişkin tartışmaların paralel bir anlayışla entegre edilmesiyle mümkün olabilir. Bölüm müfredatıyla ilgili düzenli toplantılar yapılması, bu toplantılarda çeviri etiğinin hangi stratejilerle ele alınabileceği üzerine tartışılması ve etik eğitimine ilişkin dört yıllık bir yol haritası çizilmesi dersin sağlıklı yürütülebilmesi açısından büyük fayda sağlayabilir.

Derste karşılaşılabilecek bir başka zorluk da öğrencilerin bireysel hassasiyetlerinden, inanç ya da ideolojilerinden doğabilecek çatışmalardan kaynaklanabilir. Öğrencilerin görüşlerini rahatça dile getirebildikleri, demokratik bir sınıf ortamı hedefliyor olsak da böyle bir ortamın yaratılması etik gibi kaygan zeminli bir konunun ele alındığı, kestirmeci bir anlayışla kesin doğrulara varmayı amaçlamayan bir derste kuşkusuz hayli zordur. Bu noktada eğitmen dersin temel ilkelerini öğrencilere en baştan sunarak önlem alabilir. En az bir ders saatini ayırmak suretiyle dersin amacını, kapsamını, işleniş biçimini, haftalık programı ve değerlendirme sistemini öğrencilere sunabilir; derste ağız dalaşı, kavga, hakaret gibi olumsuzlukların yaşanmaması gerektiğini, farklı bakış açılarının özellikle teşvik edildiğini, dersin temelde ahlaki sorunları tespit edebilme, empati kurabilme, tartışma, sunulan argümanı temellendirebilme gibi becerileri geliştirmeye yönelik bir ders olduğunu öğrencilere anlatabilir. Öte yandan, değerlendirme ve tartışma üzerine kurulu bir derste eğitmenin ahlaki yargılarıyla çelişebileceği kaygısıyla öğrencilerin fikirlerini özgürce dile getirememesi gibi bir sorun da yaşanabilir. "Eğitmenin kendi ahlaki yargılarına sahip olma hakkı ile sınıfı rahatça düşünce üretilebilecek bir açık alan haline getirme sorumluluğu arasında" bir denge tutturabilmesi gerçekten de çok zor olabilir (Baker ve Maier, 2011, s. 8). Bu noktada, gene ilk derste değerlendirme ölçütlerini öğrenciye sunmak ve eğitmenin de bir birey olarak yargıları ve ahlaki seçimleri olabileceğini ama bu seçimlerin öğrencilerin başarı değerlendirmesinde etkili olmayacağını belirtmek belli ölçüde fayda sağlayabilir. Kuşkusuz eğitmenin yürüteceği tüm derslerde kendi düşünce ve yargılarını öğrencilere dayatmaktan kaçınmaya çalışması kilit önem taşıyacaktır.

\section{Dersin kapsamı, amaçlar, kullanılacak yöntem ve araçlar}

Lisans düzeyinde verilecek bu çeviri etiği dersi yalnızca meslek ilkelerinin belletilmesi temelinde ilerlemeyecek olsa da, farklı meslek örgütleri tarafından ortaya koyulan meslek ilkelerinin öğrenciler 
tarafından irdelenmesi, bunun da meslek ilkelerinin gerçek hayattaki uygulamalara nasıl yansıdığı ya da yön verdiği üzerinden yapılması önem arz etmektedir. Zira çevirinin uygulamalı bir alanı olan çeviri etiği bağlamında uygulamadan tümüyle kopuk, yalnızca kuramsal veriler doğrultusunda ilerleyen bir ders yetersiz kalacaktır. Bu doğrultuda meslek ilkelerinin ve çevirmen-işveren/piyasa ilişkilerinin ders içinde ayrıntılı bir biçimde ele alınması öngörülmüştür. Eğitmen, dönem boyunca iki defadan az olmamak kaydıyla öğrencileri uzman çevirmenlerle ve meslek örgütü temsilcileriyle bir araya getirerek onların meslek hakkında bilgi ve bilinç kazanmasını, uzman çevirmenlerin sorunları, sorumlulukları, gerçek hayatta meslek ilkelerinin nasıl algılandığı, nasıl işlev gördüğü gibi meseleler üzerine düşünmesini sağlamaya çalışacaktır. Bu buluşmalar sonrasında eğitmenin sorularıyla yönlendireceği derslerde ise öğrencilerin uzman çevirmenlerin deneyimlerinden nasıl sonuçlar çıkardıkları tartışmaya açılabilir. Bu tartışmalar öncelikle öğrencilerin bir çevirmen olarak hâlihazırdaki bireysel hak ve özgürlüklerinin, sorumluluklarının bilincine varmaları, fakat daha önemlisi çeviriyle ilgili yasal düzenlemeler, çeviri sektöründeki yaygın uygulamalar ve meslek ilkelerinin işlevleri bağlamında eleştirel ve sorgulayıcı bir bakış açısı geliştirebilmeleri açısından büyük fayda să̆layabilir.

Çeviri etiğine ilişkin kuramsal yaklaşımlar da kuşkusuz dersin temel taşlarından biri olacaktır çünkü “alınacak [ahlaki] kararların sonuçları üzerine eleştirel düşünme becerisinin geliştirilebilmesi” ancak "kavramsal araçlar[ın]" kullanılmasıyla, yani kuramsal yaklaşımların yardımıyla mümkün olabilir (Baker ve Maier, 2011, s.4). Bu çerçevede, çeviri etiği alan yazınında öne çıkan yaklaşımların ders içinde ele alınması kaçınılmazdır. Ancak ders bağlamında yapılacak kuramsal okumalara ilişkin olarak ille de kronolojik bir ilerleme hedeflenmesi gerekmeyebilir. Bir başka deyişle, çeviri etiğine ilişkin kuramsal yaklaşımların tarihsel olarak nasıl evrildiğini gözler önüne sermek dersin ana amaçlarından biri değildir. Bu noktada önemli olan, daha önce çeviri kuramları ve/veya çeviri tarihi gibi dersler almış olduğu varsayılan öğrencilerin çeviri etiğine ilişkin belli başlı yaklaşımları hâlihazırdaki mesleki uygulamalarla ilişkilendirebilmesi ve somutlaştırabilmesidir. Eğitmen tarafından seçilecek kuramsal okumalar en çok da, öğrencilerin çok yönlü düşünebilme, "eşdeğerlik”, "tarafsızlık", "nesnellik” gibi kavramların katı yorumlarına eleştirel bakabilme ve dolayısıyla meslek ilkelerini sorgulayabilme becerilerini artırma gibi amaçlara hizmet edecektir.

Rosalind M. Gill ve Maria Constanza Guzman'a göre (2011) “çeviri eğitimi denince yalnızca teknik beceri, teknoloji kullanımı ve uzmanlaşma akla gelmemeli. [...] Çeviri eğitimi çeviri etkinliklerinin gerçekleştiği toplumsal koşulların bir eleştirisini de içermeli” (s. 98). Genelde çeviri eğitimi, özel olarak da çeviri etiği eğitimi bağlamında toplumsal bilincin uyandırılması gerektiğini, bu gereğin yerine getirilmemesinin ise "daha büyük bir toplumsal soruna" işaret ettiğini dile getiren araştırmacıların bu görüşlerinden yola çıkarak çeviri etiği dersinin odağına toplumsal sorun ve eşitsizliklerin yerleştirilmesi gerektiği iddia edilebilir (s. 95). Bu doğrultuda, daha önce de değinildiği gibi dersin temelini çevirmenin gerçek hayatta karşılaşabileceği ahlaki açmazlar üzerine yapılacak tartışmalar oluşturacak, toplumsal eşitsizliklerden, yani din, ırk, cinsiyet, statü, yaş, dış görünüş ve coğrafya kaynaklı eşitsizliklerden kaynaklanabilecek ve çevirmeni ahlaki seçimler yapmak zorunda bırakabilecek durumların etkileşimli bir sınıf ortamı içinde ele alınması dersin ana amaçlarından biri olacaktır. Bu türden durumları sınıf içine taşımanın en iyi yollarından biri öğrencilere senaryolar vererek onlardan senaryodaki durumlar üzerine bir değerlendirme yapmalarını istemektir. Senaryolar eğitmen tarafından dikkatle oluşturulmalı, ele alınacak her bir senaryonun öğrencinin çeviri etiği algısına nasıl bir katkı sağlayabileceği, senaryoyla ilgili tartışmanın eğitmen tarafından nasıl ve ne ölçüde yönlendirileceği, senaryo bağlamında kuramsal yaklaşımların öğrenciye nasıl yol gösterebileceği önceden değerlendirilmelidir. Hayal gücü ve yaratıcı yazarlık becerisinden çok çeviri dünyasında neler olup bittiğine, alan yazınına ve sektörel uygulamalara ilişkin bilgi ve birikimleri bu senaryoların yazılması sırasında eğitmene kılavuzluk edecektir. Dünyadaki 
başka çeviri derslerinde izlenen stratejilerden ve kullanılan senaryolardan, işveren ya da çevirmenlerin beklentilerini ya da temel anlayışlarını yansıtan açıklamalarından, haber yapılan, gündemde tartışılan yahut bir biçimde ses getiren çeviri olaylarından esinlenebilecek olan eğitmen, ayrıca senaryoların gerçeklikten kopuk olmamasına özen göstermeli, öğrencilere pekâlâ içinde bulunabilecekleri bir durum sunmak, onları kendi kültürlerinde, kendi doğal çalışma ortamlarında karşılaşabilecekleri durumlar üzerine değerlendirme yapmaya teşvik etmek için çaba harcamalıdır.

Her bir ders için öğrenciye sunulacak ve üzerinde tartışılacak bu senaryoların önemli bir tamamlayıcısı ise gene eğitmen tarafından açlacak olan sınıf blogudur. Sınıf blogu sınıf içinde yapılacak tartışmaların sınıf dışına taşınarak biraz daha geliştirilmesine yardımcı olacak, öğrencilerin dersten sonra konuyla ilgili daha ayrıntılı düşünmesine zaman ve olanak verecek ve derste tartışlan meselelerin içselleştirilmesinde büyük fayda sağlayacaktır. Blogda eğitmen tarafından yöneltilen soruları yanıtlamaları istenen öğrenciler sınıf içi tartışması esnasında yaptıklarından daha kapsamlı yorumlar yapma, senaryodaki ahlaki meseleyi daha derinlemesine ve farklı açlardan ele alma firsatını da böylece yakalayabileceklerdir. Senaryolar üzerine yapılan yorum ve yürütülen sınıf içi ve blog tartışmalarıyla hedeflenen, öğrencilerin "son derece masum görünen durumların bile ahlaki açıdan ne denli karmaşık" olabileceğini, yani çevirinin doğası gereği ahlaki seçimler yapmak zorunda kalacakları bir iş olduğunu fark etmeleri, alacakları kararların sonuçlarını öngörebilmeleri, bu kararları açıklayabilmeleri ve işin nihai ahlaki sorumluluğunu üstlenebilme becerisi geliştirebilmeleridir (Floros, 2011, s. 88).

\section{Değerlendirme}

Bir dersin en önemli unsurlarından biri de değerlendirmedir. Bu derste değerlendirmenin daha çok öğrencilerin sınıf içindeki tartışmalara ve blog tartışmalarına katılım ve katkıları üzerinden yapılması öngörülmüştür. Bunların yanında eğitmen arzu ederse öğrenciye araştırma ödevleri verebilir, sunumlar yaptırabilir; hatta yoruma dayalı açık kitap sınav biçiminde olması kaydıyla bir dizi sınav yapmayı da düşünebilir. Eğitmenin değerlendirme sırasında kullanacağı ölçütler ise verilen senaryolar ya da ele alınan güncel tartışma konuları çerçevesinde etik sorunları tespit edebilme, ahlaki seçimlerin doğrudan ve dolaylı sonuçlarını öngörebilme ve kapsamlı düşünme ve akıl yürütme becerisi biçiminde sıralanabilir. Değerlendirmeyle ilgili en önemli hatırlatma eğitmenin sınıf içi tartışmalar sırasında yapılacak yorumlara ya da ifade edilen bireysel seçimlere ilişkin "doğru/yanlış" nitelemelerinden kaçınması gerektiğidir. Drugon ve Megone’un (2011) ifadesiyle, doğru bir ahlaki değerlendirme yapmak demek "(doğru) yanıtı bulmak demek değil, çevirmenin vereceği kararı temellendirebilmesini sağlayacak akıl yürütme becerilerine sahip olması demektir" (s. 189). İyi bir çeviri etiği eğitimi "ayrıntılı düşünebilme becerisine" dayalı olmalıdır, "yapılabileceklerin ve yapılamayacakların sıralandığı otoriter bir listeye değil” (Baker ve Maier, 2011, s. 4). Öyleyse, ahlaki açmazların kestirme yollarla çözümlenebileceği ve ahlaki açıdan tek bir doğru olduğu izlenimini uyandıran "doğru/yanlış" nitelemelerinin tasarlanan bu dersin temel ilkeleriyle ters düştüğü açıktır. Ayrıca, eğitmenin bu türden kesin yargılar sunması öğrencilerin kendilerine güvenlerini azaltarak derse ve blog tartışmalarına katılım oranını düşürebilir. Bunun yerine eğitmenin öğrencilerle birebir görüşmeler yapmak ya da ortak eğilimleri ders içinde topluca ele almak yoluyla geribildirim vermesi, bu geribildirimlerde öğrencileri soracağı sorularla yönlendirmesi daha sağlıklı olacaktır.

\section{Örnek senaryo}

Yukarıda genel çerçevesini çizmeye çalıştığım çeviri etiği dersinin nasıl uygulamaya koyulacağını derste sunulması planlanan bir örnek senaryo üzerinden somutlaştırmaya çalışacağım. Senaryo şöyle: 
Avusturya'da mahkeme çevirmeni olarak çahş̧ıorsunuz. Yaptığımız iş karşılığında aldiğımız ücret Avusturya hükümeti tarafindan ödeniyor. Bir sığınma başvurusu duruşmasında çevirmenlik yapmak üzere göreve çağrıldınız. Sığınma talebiyle Avusturya hükümetine başvuran genç bir Türk kadın ile duruşmayı yürüten üç erkek resmi görevli arasında iletişim sağlamakla yükümlüsünüz. Çok geçmeden başvuru sahibinin tecavüze uğramış, ailenin erkekleri tarafindan öldürülme tehdidiyle karşı karşıya, ilkokul eğitimini tamamlayamamış, dolayısıyla ifade becerileri sınırl, travmatize olmuş 20 yaşlarında bir kadın olduğunu anliyorsunuz. Bu kadının başvurusunu değerlendirmek üzere orada bulunan resmi görevlilerin sordukları sorulardan ve yüz ifadelerinden yola çıarak bu kişilerin belki de yaptıkları görevin doğası gereği başvuru sahibinin ifadelerine kuşkuyla yaklaştığın fark ediyorsunuz. Genç kadın ise hikâyesini akıcı biçimde anlatmak ve ayrintıll sorulara düzgün yantlar vermek konusunda zorlaniyor.

Bu senaryoyu öğrencilere verdikten sonra eğitmen önceden hazırladığı soruları tek tek sinıfa yönelterek tartışmayı yönlendirmeye ve derinleştirmeye çalışır. Eğitmenin sorabileceği sorular şunlar olabilir:

1. Çevirmenden beklenen nedir?

2. Bu durumda çevirmen ne tür sorunlar yaşayabilir? Bu sorunlar neden kaynaklanıyor olabilir?

3. Çevirmene hangi meslek ilkeleri yol gösterebilir?

4. Çevirmen ne tür kararlar alabilir? Bunların olası sonuçları neler olabilir?

5. Çevirmen güç dengesizliğini ortadan kaldırmaya yönelik stratejiler uygulayabilir mi? Örneğin, hikâyesini akıcı ve tutarlı biçimde ifade edemeyen sığınmacıya söylediklerini tekrar etme şansı verme ya da cümleleri daha akıcı ve bir Batılı için daha anlaşılır hale getirme yoluna gidebilir mi?

Açıkça görüldüğü gibi 1. ve 3. sorular öğrencilerin daha önceden öğrendikleri ya da üzerine düşündükleri "doğruluk", "tarafsızlık", "sadakat" gibi meslek ilkelerini bu senaryodaki durumla bağdaştırabilmelerini hedefleyen sorular. 2. soru ise öğrencilerin verili durumdaki güç eşitsizliğini tespit edebilmelerini sağlamak amacıyla sorulmuş. Çevirmen kararlarıyla ve stratejileriyle ilgili olan 4 . ve 5 . sorular ise eğitmenin tartışmayı ne yönde derinleştirmek istediğine işaret ediyor. Eğitmen bu sorularla sınıf içi tartışmayı yeterince derinleştirdiğine hükmettiğinde öğrencilere evde okumaları için bir makale verir. Sonja Pöllabauer'in kaleme aldığı “'Translation Culture' in Interpreted Asylum Hearings” ["Sı̆̆ınma Başvurusu Duruşmalarında 'Çeviri Kültürü’”] (2006) başlıklı bu makalede duruşma tutanakları üzerinden Avusturya göçmen büroları için çalışan çevirmenlerin kullandıkları stratejiler incelenmektedir. Araştırmacı yaptığı incelemede çevirmenlerin hangi durumlarda hangi tarafla "işbirliği” içine girdiğini belirlemeye çalışmış ve ilginç sonuçlarla karşılaşmıştır. Bu sonuçlara göre "işbirliği” özellikle çevirmenler ile duruşmada soruları yönelten resmi görevliler arasında ortaya çlkmaktadır. Yani, çevirmenler anlaşmazlık durumlarında açıklamalar ya da düzeltmeler yaparak görevlilerin doğru anlaşılmasını sağlamaya çalışırlar, hatta bazı durumlarda, çevirmenler görevlilerin asistanları gibi davranmaya başlarlar. Buna karşılık, iki taraf arasındaki güç dengesizliğini ortadan kaldırmaya yönelik müdahaleler yapmak konusunda çekimser ya da isteksizdirler. Kısacası, çevirmenler mesleki eğitimler sırasında kendilerine ısrarla öğretilen "tarafsızlık" ilkesi uyarınca başvuru sahibine karşı mesafeli olmaya çalışır ama benzer bir davranışı otorite kabul ettikleri görevli memurlara karşı gösteremez, tam aksine otoriteyle "işbirliği”" yapmayı tercih ederek, bir anlamda, "tarafsızlık" ilkesini çiğnemiş olurlar. Demek ki, "tarafsızlık" ilkesi, güç eşitsizliğinin belirgin ve belirleyici olduğu bu türden bir ortamda güçlünün yanında olma tutumuna dönüşür, çevirmenin sözde tarafsızlığı güçlünün avantajı, güçsüzün ise dezavantajı haline gelir. Öğrencilere evde okumaları için verilen bu makalede varılan sonuçlar henüz sınıf içinde tartışılmayacaktır. Makale, daha çok, dersin ikinci aşamasına geçiş yapmak, yani öğrencilerin duruma eleştirel yönden bakabilmelerini ve sınıf içinde önceden yürütülen tartışmayı içselleştirmelerini sağlamak için bir araç işlevi görmektedir. Ertesi gün eğitmen sınıf bloguna yazacağı sorularla sözü edilen bu süreci yönlendirmeye, tartışmayı daha da derinleştirmeye çalışacaktır. Öğrencilerden makalede varılan sonuçlardan yola çıkarak senaryodaki çevirmenin durumunu ve 
uygulayabileceği stratejileri yeniden ele almalarını isteyen eğitmen makaleyi okuduktan sonra öğrencilerin görüşlerinin değişip değişmediğini, "doğruluk" ve "tarafsızlık" gibi meslek ilkeleriyle ilgili ne tür sonuçlar çıkartabildiklerini, bunlara eleştirel biçimde yaklaşıp yaklaşmadıklarını blog yanıtları üzerinden değerlendirmeyi amaçlar.

\section{Sonuç}

Çeviri etiği eğitiminde temel amaç, norm koymak ya da var olan normları öğrencilere belletmek değil, çevirmen adayının doğru değerlendirme yapmasına olanak verecek bir ortam hazırlamak, böyle bir değerlendirme yapmasını mümkün kılacak bilgi ve verileri ona sunmak, alacağı karar her ne olursa olsun bu kararın sonuçlarını öngörebilmesini ve bilinçli tercihler yapmasını sağlamaya çalışmak ve en önemlisi bir çevirmen olarak yaptığı işin ahlaki sorumluluğunu üstlenmesi gerektiği bilincini ona aşılamak olmalıdır. Var olan meslek ilkelerini mercek altına alıp bunları sorgulatan, felsefi düşünceden, çağdaş çeviri kuramlarının sunduğu yeni bakış açlarından ve güncel araştırmalardan beslenen, farkındalığı artırıcı, çevirmenin bireysel ahlaki seçimlerine saygılı bir çeviri etiği dersi, mesleklerini yaparken çevirmenlere kuşkusuz meslek ilkelerinden çok daha fazla yol gösterici olacaktır. Fakat bu, meslek ilkelerinin tümüyle gereksiz olduğu anlamına gelmiyor. Meslek ilkeleri, Kuçuradi’nin ifadesiyle söylemek gerekirse, "her meslekte sorumsuz insanlar bulunabileceği için" hiç kuşkusuz son derece gereklidir (Kuçuradi 1995, aktaran Tepe, 2009, s. 158). Ancak meslek ilkeleri tek başlarına çevirmenlerin her tek durumda ahlaki ikilemlerden kolayca kurtulabilmelerini, doğru değerlendirme yapabilmelerini sağlamayacağı gibi, nasıl ele alındıklarına bağlı olarak çevirmenlerin eleştirel ve sorgulayıcı bir bakış açısı geliştirmelerini, yaptıkları işin doğrudan ve dolaylı sonuçları üzerine düşünmelerini ve bireysel sorumluluk duygusuyla hareket etmelerini engelleyebilir.

\section{Kaynakça}

Abdallah, K. (2011). "Towards Empowerment”. The Interpreter and Translator Trainer, 5:1, 129-154.

Arrojo, R. (2005). "The Ethics of Translation in Contemporary Approaches to Translator Training". Training for the New Milennium, 225-245.

Baker M. and C. Maier. (2011). "Ethics in Interpreter and Translator Training". The Interpreter and Translator Trainer, 5:1, 1-14.

Bauman, Z. (1998). Postmodern Etik. çev. Alev Türker. İstanbul: Ayrıntı Yayınları.

Derrida, J. (1991/1992). The Other Heading. Trans. P.-A. Brault and M.B. Naas. Bloomington: Indiana University Press.

Drugan J. and Chris Megone. (2011). "Bringing Ethics into Translator Training”. The Interpreter and Translator Trainer, 5:1, 183-211.

Eruz, S. (2012). "Çeviri Derneği ve Türkiye'de Çevirmenlik Mesleğinin Statüye Kavuş(a)ma(ma)sı Üzerine On Üç Yıllık Gel Gitli Bir Öykü”. Avrupa Birliği Bakanlığı Çeviri Platformu Bildirileri, İstanbul, 17-23.

Floros G. (2011). "Ethics-less' Theories and 'Ethical' Practices". The Interpreter and Translator Trainer, 5:1, 65-92.

Gill R. M. and M. Constanza Guzman. (2011). "Teaching Translation for Social Awareness in Toronto". The Interpreter and Translator Trainer, 5:1, 93-108.

Kuçuradi, İ. (2009). "Felsefi Etik ve Meslek Etikleri”. Etik ve Meslek Etikleri. ed. Harun Tepe. Ankara: Türkiye Felsefe Kurumu: 27-43.

McDonough Dolmaya, J. (2011). "Moral Ambiguity: Some Shortcomings of Professional Codes of Ethics for Translators". The Journal of Specialised Translation, Issue 19, 28-49. 
Pöllabauer, S. (2006). “Translation Culture' in Interpreted Asylum Hearings”. Sociocultural Aspects of Translating and Interpreting. ed. Anthony Pym, Miriam Shlesinger, Zuzana Jettmarova. Amsterdam/Philadelphia: John Benjamins: 151-162.

Tellioğlu, B. (2015). Çeviride Makul, Makbul ve Müphem: Çeviri Etiği, Meslek Ilkeleri ve Bireysel Ahlak. Yayımlanmamıs, doktora tezi. Yıldız Teknik Üniversitesi Sosyal Bilimler Enstitüsü, Istanbul.

Tepe, H. (2009). "Basın Etiği” ya da Basının Etik Sorunları. Etik ve Meslek Etikleri. Yay. Haz. Harun Tepe. Ankara: Türkiye Felsefe Kurumu: 141-160. 